\title{
RESEARCH PAPER \\ Foliar fertilization in the propagation of conilon coffee in alternative substrates
}

\author{
Sávio da Silva Berilli' ${ }^{1}$ Ramon Amaro de Sales ${ }^{2}$, Helder Rodrigues Ribeiro', \\ Alan Alvino Falcão Zooca ${ }^{1}$, Rodrigo Amaro de Salles ${ }^{3}$, Ana Paula Candido \\ Gabriel Berilli', Wilian Rodrigues Ribeiro ${ }^{3}$, Silvio de Jesus Freitas ${ }^{4}$, and \\ Taiara Souza Costa ${ }^{5}$ \\ 'Instituto Federal do Espirito Santo - Campus Itapina. Highway BR 259, Colatina, Espirito Santo, Brasil \\ ${ }^{2}$ Universidade Federal de Viçosa. Av. Peter Henry Rolfs, Viçosa, Minas Gerais, Brasil \\ ${ }^{3}$ Universidade Federal do Espirito Santo. Alto Universitário, Alegre, Espirito Santo, Brasil \\ ${ }^{4}$ Universidade Estadual do Norte Fluminece. Av Alberto Lamego, 2000, Campos dos Goytacazes, Rio de \\ Janeiro, Brasil \\ ${ }^{5}$ Universidade Estadual de Feira de Santana. Highway R-116, Km 03, Av. Universitária, Feira de Santana, \\ Bahia, Brasil
}

\begin{abstract}
S.S. Berilli, R.A. Sales, H.R. Ribeiro, A.A.F. Zooca, R. A. Salles, A.P.C.G. Berilli, W.R. Ribeiro, S.J. Freitas, and T.S. Costa. 2020. Foliar fertilization in the propagation of conilon coffee in alternative substrate. Int. J. Agric. Nat. Resour. Tannery sludge has been highlighted for substrate use in the propagation of seedlings, combining the solution of an environmental problem with its potential for agronomic use. However, when a new fertilizer component enters into the composition of a substrate, it remains to be seen whether other characteristics are affected. Thus, the objective of this work was to verify whether supplementary foliar fertilization is necessary when using a substrate with tannery sludge in the propagation of conilon coffee seedlings of the variety "Vitótria Incaper - 8142". A $2 \times 13$ factorial arrangement was used, the first factor being the presence or absence of conventional leaf fertilization, and the second factor being the 13 coffee conilon Vitoria-Incaper 8142 genotypes arranged in a randomized complete block design with four replications. The genotypes V7 and V9 presented leaves of reduced size, leading to a smaller leaf area, which coincided with a lower accumulation of aerial and total dry matter mass. Higher flavonoid indexes were found in the genotypes V1, $\mathrm{V} 2$, V6, and V13, indicating a higher sensitivity of these materials to the components present in the tannery sludge. In general, fertilization provided better initial development as well as a better seedling quality index.
\end{abstract}

Keywords: Coffea canephora, physiology, propagation, sustainability.

\section{Introduction}

The constant production of solid waste generated by industries has become the primary source of

Received Feb 23, 2019. Accepted Mar 23, 2020.

Corresponding author: rodrigoamarodesalles@hotmail.com pollution worldwide. Silva et al. (2019) suggested that if not properly disposed of, solid waste can cause severe damage to the environment. According to the authors, one of the possible solutions would be the reutilization of solid waste, for example, as an alternative substrate, 
generating savings and, above all, improvements for the environment.

The use of organic residues in agriculture has increasingly aroused the attention of researchers and led to increased efforts to demonstrate their effects on several species of interest, with the objective of reducing the environmental impact generated by the disposal of these materials (Restrepo et al., 2013; Sales et al., 2017). There is a strong potential for the use of industrial residues, which are strongly correlated with the growth and physiology of agricultural plants, as observed by Oberpaur et al. (2012), Sales et al. (2018a), Berilli et al. (2018a) and Quartezani et al. (2018).

Among organic residues, it is possible to highlight the tannery sludge generated by the leather processing industries, which presents enormous potential for use in agriculture. This residue contains a high content of organic matter and mineral elements, which are essential for the development of plants (Tavares et al., 2013; Berilli et al., 2018b). It can be used both in liquid and solid form and incorporated into substrates for use in the propagation of seedlings (Sales et al., 2018b; Berilli et al., 2018b).

The coffee industry in Brazil is fundamentally important for economic and social development; the productivity of the workforce, job security, the generation of jobs, and tax collection are particularly important (Ferrão et al., 2008). According to data compiled by CONAB (2018), Brazil is the world's largest producer and exporter of coffee, with an estimated harvest of 58 million bags in 2018, 24\% of which is conilon coffee (Coffea canephora Pierre).

The conventional method of conilon coffee seedling production depends on complementary foliar fertilization through leaves. However, there are no studies that show the effect of foliar fertilization when alternative substrates, such as tannery sludge, are used. It is known that tannery sludge is a nutrient-rich component that can be made available to plants over long periods, (Araújo et al., 2008), thus serving as a replacement for foliar fertilization. The objective of this work was to verify whether supplementary foliar fertilization is necessary when using a substrate with tannery sludge in the propagation of conilon coffee seedlings of the variety "Vitótria Incaper - 8142".

\section{Material and Methods}

The experiment was carried out at the seedling propagation nursery of the Federal Institute of Education, Science and Technology of Espírito Santo, Campus Itapina, located in the municipality of Colatina, ES (19 $32^{\prime} 22^{\prime \prime} \mathrm{S}, 40^{\circ} 37^{\prime} 50^{\prime}$ W; 71 meters above sea level). The climate of the region is Tropical Aw, according to the climatic classification of Köppen, with a well-defined rainy season between October and January and an average climatological precipitation of $1029.9 \mathrm{~mm}$ (Sales et al., 2018c). A $2 \times 13$ factorial arrangement was used, considering the presence or absence of conventional foliar topdressing fertilization as the first factor. The second factor was the 13 conilon coffee genotypes. The treatments were arranged in a complete randomized block design with four replicates. Each treatment contained seven seedlings, totaling 182 plants per block, and 728 plants in all the experiments.

The substrate was prepared 30 days in advance in the following composition: $20 \%$ dehydrated tannery sludge, $30 \%$ humus and $50 \%$ red ravine soil. After the homogenization of the components, $600 \mathrm{ml}$ polyethylene bags were filled, and beds were formed.

Seedlings of coffee conilon (C. canephora) were obtained from the variety "Vitória Incaper 8142" (13 genotypes) produced at the aforementioned institute. The seedlings were obtained from cuttings of orthotropic branches of adult tissue, removed from crops with adequate phytosanitary and nutritional characteristics. After the removal of the branches of the mother plants, they were 
moved to the greenhouse, where $30 \mathrm{~cm}$ of the ends of the orthotropic branches were removed. Then, the cuttings were standardized between 6 and $8 \mathrm{~cm}$ in height, leaves with $1 / 3$ of the leaf area, plagiotropic branches and $1 \mathrm{~cm}$ retained above the leaf pair insertion. The cuttings were planted as soon as they were prepared in a previously wetted substrate.

The seedlings underwent foliar fertilization (three applications) with nitrogen and potassium using $0.3 \mathrm{~g}$ of urea and $0.3 \mathrm{~g}$ of potassium chloride, filled to a $100 \mathrm{~mL}$ volume with water. This solution contained $1.35 \mathrm{~g} \mathrm{~L}^{-1}$ of $\mathrm{N}$ and $1.80 \mathrm{~g} \mathrm{~L}^{-1}$ of $\mathrm{K}_{2} \mathrm{O}$, which were used in this experiment because they represent the conventional fertilization regime for the production of coffee seedlings in commercial nurseries. The first application occurred shortly after the emergence of the second pair of leaves; the subsequent applications occurred every 30 days.

The tannery sludge used in the experiment was supplied by the company Capixaba Couros LTDA, located in the municipality of Baixo Guandu, state of Espírito Santo. The residue underwent laboratory analysis to determine the values of the chemical parameters shown in Table 1.

Table 1. Result of the solid organic substrate analysis used in the experiment

\begin{tabular}{lcc}
\hline Parameter & Unit & Content \\
\hline Total organic matter & $\left(\mathrm{g} \mathrm{dm}^{-3}\right)$ & $293.60^{\dagger}$ \\
Compostable organic matter & $\left(\mathrm{g} \mathrm{dm}^{-3}\right)$ & 110.20 \\
& $\%$ & 6.12 \\
Organic carbon & - & $3 / 1$ \\
C/N ratio & $\left(\mathrm{g} \mathrm{dm}^{-3}\right)$ & 17.30 \\
Nitrogen & $\left(\mathrm{g} \mathrm{dm}^{-3}\right)$ & 5.20 \\
Phosphorus & $\left(\mathrm{g} \mathrm{dm}^{-3}\right)$ & 0.60 \\
Potassium & $\left(\mathrm{g} \mathrm{dm}^{-3}\right)$ & 226.90 \\
Calcium & $\left(\mathrm{g} \mathrm{dm}^{-3}\right)$ & 15.30 \\
Magnesium & $\left(\mathrm{g} \mathrm{dm}^{-3}\right)$ & 13.20 \\
Sulfur & $\left(\mathrm{g} \mathrm{dm}^{-3}\right)$ & 5.50 \\
Sodium & $\left(\mathrm{g} \mathrm{dm}^{-3}\right)$ & 37.00 \\
Chromium & $\left(\mathrm{g} \mathrm{dm}^{-3}\right)$ & 0.26 \\
Boron &
\end{tabular}

${ }^{\dagger}$ Results based on dry matter (mass/mass)
The experiment lasted 150 days, during which time the plants reached a commercial size. The following characteristics were evaluated: leaf number (LN), plant height (height), stem diameter (SD), and leaf area (LA) measured with the aid of the LI-3100C (LI-COR, Nebraska USA) device. The leaf chlorophyll index was measured by a SPAD-502-PLUS (Konica Minolta, Japan). In addition, the dry matter mass of the aerial part $(\mathrm{APDM} m)$, root dry matter mass (RDMm) and total dry matter mass (TDM $m$ ) were evaluated. The dry matter mass was obtained by incubating the material in a forced air circulation oven at 72 ${ }^{\circ} \mathrm{C}$ for $72 \mathrm{~h}$ and then weighing it on a precision analytical scale. After obtaining these data, the leaf area ratio (LAR), obtained through Eq. 1, was calculated in $\mathrm{cm}^{2} \mathrm{~g}^{-1}$, and the Dickson Quality Index (DQI) of the seedlings was obtained by Eq. 2 .

$$
\begin{aligned}
& \mathrm{LAR}=\left(\frac{\mathrm{LA}}{\mathrm{TDM} m}\right) \quad-\text { Eq. } 1 \\
& \mathrm{IQD}=\frac{\mathrm{TDM} m}{\left(\left(\frac{\text { Height }}{\mathrm{SD}}\right)+\left(\frac{\mathrm{APDM} m}{\mathrm{RDM} m}\right)\right)} \quad-\text { Eq. } 2
\end{aligned}
$$

In addition to the SPAD chlorophyll index and leaf area, the leaf physiology analyses were performed with a multiplex ${ }^{\circledR}$ (Force-A, France) fluorometer with multiple light excitation sources. The indexes of various compounds, such as nitrogen balance (NBI-R), total chlorophyll (SFR-R) and flavonoids (FLAV) were estimated. The analyses were performed in the morning between $9 \mathrm{~h} 00$ a.m. and 11h00 a.m. and on only one side of the seedlings. The equipment was pointed toward the canopy, from top to bottom, at an angle of approximately 45 degrees.

The data were analyzed with an analysis of variance and $F$ test and, when significant, a Scott-Knott test 
was used at a 5\% significance level. R software was used for the analyses.

\section{Results and Discussion}

The V3 genotype of the "Vitória - Incaper 8142" variety was not analyzed in this experiment because of the low survival index of the seedlings (approximately 20\%). According to Dardengo et al. (2010), this genotype is considered intrinsically difficult to propagate.

The analysis of variance in Table 2 indicates that there was no significant interaction between the factors studied (leaf fertilization $x$ genotypes) for any of the characteristics evaluated in conilon coffee trees of the variety "Vitória - Incaper 8142 ". Therefore, only the simple effects of the factors (genotypes and foliar fertilization) on the developmental variables of the seedlings were analyzed.

A significant effect of the genotypes was observed (Table 2) for all of the characteristics evaluated, except for the number of leaves, plant height, and LAR index. These results show that the initial development is not uniform among the genotypes of the variety studied. According to Contarato et al. (2010), the genotypes of this variety are divided into two groups for initial development, with one group being superior over the other. Regarding the fertilization levels (Table 2), only the SPAD and LAR variables, together with the physiological variables of total chlorophyll, nitrogen balance and flavonoid index, did not have a significant effect; that is, foliar fertilization promoted the development of the conilon coffee seedlings but did not influence the evaluated physiological variables.

Table 3 shows the effect of conventional foliar fertilization on the development of conilon coffee seedlings. Except for the SPAD (Table 3) and leaf area ratio (Table 4) variables, all the other evaluated characteristics showed significant increases in the treatments that received foliar fertilization. This highlights the importance of complementary fertilization even on an alternative substrate with the use of tannery sludge,

Table 2. Summary of the analysis of variance of the characteristics of "Vitória Incaper 8142" conilon coffee seedlings: plant height (Height), stem diameter (SD), leaf number (LN), leaf area (LA), leaf chlorophyll index (SPAD), mass of the dry matter of the aerial part of the plant (APDMm), root dry matter mass (RDMm), total dry matter mass (TDMm), leaf area ratio (LAR), Dickson quality index (DQI), total chlorophyll (SFR-R), nitrogen balance index (NBI-R) and flavonoid index (FLAV).

\begin{tabular}{|c|c|c|c|c|c|c|c|c|}
\hline \multirow[b]{2}{*}{ Source of variation } & \multirow[b]{2}{*}{$\mathrm{DF}$} & \multicolumn{7}{|c|}{ Mean square (QM) } \\
\hline & & Height $(\mathrm{cm})$ & $\begin{array}{c}\mathrm{SD} \\
(\mathrm{mm})\end{array}$ & $\mathrm{LN}$ & $\begin{array}{c}\text { LA } \\
\left(\mathrm{cm}^{2}\right)\end{array}$ & SPAD & $\begin{array}{l}\text { APDM } m \\
(\mathrm{~g})\end{array}$ & $\begin{array}{c}\mathrm{RDM} m \\
(\mathrm{~g})\end{array}$ \\
\hline Genotypes & 11 & $15.95^{\mathrm{ns}}$ & $0.506^{* *}$ & $3.73^{\text {ns }}$ & $7902 * *$ & $112.81 * *$ & $0.97 * *$ & $0.11 * *$ \\
\hline Foliar fertilization & 1 & $142.67 * *$ & $1.83 * *$ & $54.05 * *$ & $65216^{* *}$ & $4.86^{\mathrm{ns}}$ & $8.81 * *$ & $0.42 * *$ \\
\hline Genotype $\times$ foliar $\mathrm{f}$ & 11 & $5.79^{\mathrm{ns}}$ & $0.19^{\mathrm{ns}}$ & $2.12^{\mathrm{ns}}$ & $2976^{\mathrm{ns}}$ & $19.24^{\mathrm{ns}}$ & $0.29^{\mathrm{ns}}$ & $0.05^{\mathrm{ns}}$ \\
\hline Residue & 69 & 8.28 & 0.17 & 3.09 & 2578 & 15.84 & 0.36 & 0.05 \\
\hline Overall mean & & 13,83 & 3,50 & 8,39 & 211,18 & 31,77 & 3,43 & 0,70 \\
\hline $\mathrm{CV} \%$ & & 20.94 & 11.88 & 21.41 & 24.04 & 12.56 & 20.69 & 30.49 \\
\hline Source of variation & $\mathrm{DF}$ & $\begin{array}{l}\mathrm{TDM} m \\
\quad(\mathrm{~g})\end{array}$ & $\begin{array}{c}\text { LAR } \\
\left(\mathrm{cm}^{2} \mathrm{~g}^{-1}\right)\end{array}$ & DQI & SFR-R & NBI-R & FLAV & \\
\hline Genotypes & 11 & $1.65^{*}$ & $75.96^{\mathrm{ns}}$ & $0.04 * *$ & $0.49 *$ & $3.98^{*}$ & $0.08 * *$ & \\
\hline Foliar fertilization & 1 & $13.04 * *$ & $79.75^{\text {ns }}$ & $0.10^{* *}$ & $0.05^{\mathrm{ns}}$ & $0.43^{\mathrm{ns}}$ & $0.001^{\mathrm{ns}}$ & \\
\hline Genotype $\times$ foliar $\mathrm{F}$ & 11 & $0.94^{\mathrm{ns}}$ & $90.03^{\mathrm{ns}}$ & $0.02^{\mathrm{ns}}$ & $0.19^{\text {ns }}$ & $0.48^{\mathrm{ns}}$ & $0.01^{\mathrm{ns}}$ & \\
\hline Residue & 69 & 0.57 & 173.83 & 0.01 & 0.24 & 0.91 & 0.001 & \\
\hline Overall mean & & 3.59 & 60.14 & 0,44 & 2.83 & 2.53 & 0.30 & \\
\hline $\mathrm{CV} \%$ & & 21.02 & 21.92 & 26.95 & 17.22 & 37.65 & 27.17 & \\
\hline
\end{tabular}

*Significant at $5 \%$ probability $(\mathrm{p}<0.05),{ }^{*}$ Significant at $1 \%$ probability $(\mathrm{p}<0.01)$, ns: not significant. 
which is rich in nutrients and organic matter. It is important to highlight plant height and leaf area, which showed increases of $16 \%$ and $26 \%$, respectively, compared to the treatment that did not receive fertilization.

Table 3. Mean values of plant height (Height), stem diameter (SD), leaf number (LN), leaf area (LA), and leaf chlorophyll index (SPAD) of "Vitória Incaper 8142" conilon coffee seedlings, with and without fertilization

\begin{tabular}{lccccc}
\hline Fertilization & $\begin{array}{c}\text { Height } \\
(\mathrm{cm})\end{array}$ & $\begin{array}{c}\text { SD } \\
(\mathrm{mm})\end{array}$ & LN & $\begin{array}{c}\text { LA } \\
\left(\mathrm{cm}^{2}\right)\end{array}$ & SPAD \\
\hline Without & $12.52 \mathrm{~b}$ & $3.38 \mathrm{~b}$ & $7.45 \mathrm{~b}$ & $176.70 \mathrm{~b}$ & $31.92 \mathrm{a}$ \\
With & $14.96 \mathrm{a}$ & $3.66 \mathrm{a}$ & $8.96 \mathrm{a}$ & $239.97 \mathrm{a}$ & $31.47 \mathrm{a}$ \\
\hline
\end{tabular}

The means followed by the same letter are not different from each other at a $5 \%$ probability level $(\mathrm{p}<0.05)$ according to a Scott-Knott test.

The leaf area ratio is a measure related to the increase in the dry matter per leaf area; thus, although leaf fertilization provided higher values of dry matter, it also increased the leaf area, which generated a ratio proportional to that in the treatment without fertilization (Table 4).

Table 4. Mean values of the dry matter of the aerial parts of the plants (MSAm), root dry matter mass (MSR $m$ ), total dry matter mass (MSTm), Dickson quality index (DQI) of the seedlings and leaf area ratio (LAR) of "Vitória Incaper 8142" conilon coffee seedlings, with and without leaf fertilization

\begin{tabular}{lccccc}
\hline Fertilization & $\begin{array}{c}\mathrm{APDM} m \\
(\mathrm{~g})\end{array}$ & $\begin{array}{c}\mathrm{RDM} m \\
(\mathrm{~g})\end{array}$ & $\begin{array}{c}\mathrm{MST} m \\
(\mathrm{~g})\end{array}$ & DQI & $\begin{array}{c}\text { LAR } \\
\left(\mathrm{cm}^{2} \mathrm{~g}^{-1}\right)\end{array}$ \\
\hline Without & $2.59 \mathrm{~b}$ & $0.63 \mathrm{~b}$ & $3.22 \mathrm{~b}$ & $0.41 \mathrm{~b}$ & $59.22 \mathrm{a}$ \\
With & $3.20 \mathrm{a}$ & $0.76 \mathrm{a}$ & $3.96 \mathrm{a}$ & $0.48 \mathrm{a}$ & $61.05 \mathrm{a}$ \\
\hline
\end{tabular}

The means followed by the same letter are not different from each other at a $5 \%$ probability level $(\mathrm{p}<0.05)$ according to a Scott-Knott test.

Despite the greater amount of nitrogen in the treatment that received foliar fertilization, no increases were observed in the chlorophyll indexes (Table 3 and Table 5). However, greater average values of leaf number and consequently of leaf area were found, resulting in greater photosynthetic capacity, which in turn provides higher carbon fixation, thus explaining the greater stem diameter and height (Table 3) and higher total dry matter mass (Table 4).
Table 5. Mean values of chlorophyll (SFR-R), nitrogen balance (NBI-R), and flavonoids (FLAV) obtained by using a Multiplex ${ }^{\circledR}$ device with "Vitória Incaper 8142" conilon coffee seedlings, with and without leaf fertilization

\begin{tabular}{llll}
\hline Fertilization & SFR-R & NBI-R & FLAV \\
\hline Without & $2.85 \mathrm{a}$ & $2.60 \mathrm{a}$ & $0.30 \mathrm{a}$ \\
With & $2.80 \mathrm{a}$ & $2.47 \mathrm{a}$ & $0.31 \mathrm{a}$ \\
\hline
\end{tabular}

The means followed by the same letter are not different from each other at a $5 \%$ probability level $(\mathrm{p}<0.05)$ according to a Scott-Knott test.

Foliar fertilization contributed to significant gains in dry matter mass (Table 4), both to the aerial part of the plant and to the root system. The dry matter masses of the roots and aerial parts of the plants were greater by $17 \%$ and $19 \%$, respectively, than those in the plants without fertilization. Fertilization also led to the seedlings having higher quality indexes, which is a fundamental characteristic for the adequate development of the seedlings when transplanted to the field.

Foliar fertilization did not lead to any differences in the variables obtained by the Multiplex ${ }^{\circledR}$, as shown in Table 5. This result shows that despite improving the gain in several developmental characteristics, such as plant height, leaf area, and dry matter, fertilization did not change the secondary metabolism or the chlorophyll or nitrogen balance indexes of the seedlings.

It is important to emphasize that foliar fertilization did not influence nitrogen balance, even though the plants that received the applications showed improvements in several characteristics, including the seedling quality index (Table 4). These results can be explained by the nitrogen balance, which is measured by an indirect correlation of the chlorophyll content in the leaves and did not present differences (Table 3 and Table 5). Therefore, this indicates that the nitrogen supplied by the foliar fertilization did not lead to a more significant amount of nitrogen per unit of leaf area but instead led to increases in other components of the plants, such as proteins, enzymes, ATP and $\mathrm{NADPH}$, which promoted the optimal vegetative 
development and, consequently, seedlings of a better quality.

Among the variables analyzed in Table 6, only the stem diameter and SPAD index differed among the genotypes. For the stem diameter, genotypes $\mathrm{V} 1, \mathrm{~V} 2, \mathrm{~V} 4, \mathrm{~V} 6, \mathrm{~V} 10$, and V11 presented the best averages, ranging from 3.56 to $3.82 \mathrm{~mm}$, which is at least $5 \%$ higher than all the other genotypes evaluated. These results are similar to those found by Covre et al. (2013), in which stem diameter was assessed after the initial development of the 13 genotypes in a conventional substrate composed of soil, cattle manure and chemical fertilizer. The genotypes V1, V2, V3, V4, V8, V9, V10, V11, and V12 had remarkably high stem diameters. The small divergence between these experiments can be attributed to the different responses that genotypes can express when grown in different substrates.

Regarding the SPAD index (Table 6), genotypes V9 and V11 stood out as having the highest average values. Thus, it can be inferred that the V11 genotype presents a more considerable amount of chlorophyll and, consequently, accumulated nitro- gen in the leaves, since the chlorophyll molecule is formed by a central magnesium atom bound to four nitrogen atoms (Streit et al., 2005), with a higher average chlorophyll index observed for the genotype (Table 8).

It should be noted that the number of leaves of genotype V9 did not differ from that of the other genotypes; however, genotype V9 presented a smaller leaf area over the same number of leaves, meaning that the leaves of this genotype had a reduced size. This generates the hypothesis that this condition allowed the concentration of the chlorophyll molecules in a smaller area, causing a high SPAD value due to the concentration and dilution effect. The authors Sales et al. (2018b), after applying doses of tannery sludge via leaves in conilon coffee plants, observed a linear increase in the number of leaves. However, they noted that there was a reduction in leaf area for the dose that maximized the gain $\left(15.77 \mathrm{~mL} \mathrm{~L}^{-1}\right)$ and attributed this fact to the reduced leaf size, as observed in this experiment. Hence, it is possible to conclude that the use of tannery sludge in conilon coffee plants tends to increase the number of leaves and reduce the leaf area of the seedlings. In terms of

Table 6. Mean values of plant height (Height), stem diameter (SD), leaf number (LN), leaf area (LA), and leaf chlorophyll index (SPAD) of "Vitória Incaper 8142" conilon coffee seedlings

\begin{tabular}{lccccc}
\hline Genotypes & $\begin{array}{c}\text { Height } \\
(\mathrm{cm})\end{array}$ & SD $(\mathrm{mm})$ & LN & $\begin{array}{c}\text { LA } \\
\left(\mathrm{cm}^{2}\right)\end{array}$ & SPAD \\
\hline V1 & $14.66 \mathrm{a}$ & $3.61 \mathrm{a}$ & $9.70 \mathrm{a}$ & $250.73 \mathrm{a}$ & $27.45 \mathrm{~b}$ \\
V2 & $14.21 \mathrm{a}$ & $3.82 \mathrm{a}$ & $8.15 \mathrm{a}$ & $208.73 \mathrm{a}$ & $29.44 \mathrm{~b}$ \\
V4 & $13.60 \mathrm{a}$ & $3.65 \mathrm{a}$ & $7.32 \mathrm{a}$ & $192.83 \mathrm{a}$ & $29.97 \mathrm{~b}$ \\
V5 & $10.94 \mathrm{a}$ & $3.46 \mathrm{~b}$ & $8.29 \mathrm{a}$ & $217.41 \mathrm{a}$ & $28.70 \mathrm{~b}$ \\
V6 & $13.73 \mathrm{a}$ & $3.96 \mathrm{a}$ & $8.76 \mathrm{a}$ & $236.06 \mathrm{a}$ & $29.95 \mathrm{~b}$ \\
V7 & $14.01 \mathrm{a}$ & $3.26 \mathrm{~b}$ & $7.80 \mathrm{a}$ & $161.45 \mathrm{~b}$ & $31.15 \mathrm{~b}$ \\
V8 & $14.30 \mathrm{a}$ & $3.41 \mathrm{~b}$ & $7.95 \mathrm{a}$ & $223.53 \mathrm{a}$ & $31.43 \mathrm{~b}$ \\
V9 & $11.87 \mathrm{a}$ & $3.08 \mathrm{~b}$ & $8.27 \mathrm{a}$ & $143.48 \mathrm{~b}$ & $40.34 \mathrm{a}$ \\
V10 & $14.85 \mathrm{a}$ & $3.56 \mathrm{a}$ & $7.56 \mathrm{a}$ & $192.83 \mathrm{a}$ & $31.05 \mathrm{~b}$ \\
V11 & $15.98 \mathrm{a}$ & $3.73 \mathrm{a}$ & $9.07 \mathrm{a}$ & $233.93 \mathrm{a}$ & $38.07 \mathrm{a}$ \\
V12 & $12.54 \mathrm{a}$ & $3.30 \mathrm{~b}$ & $8.05 \mathrm{a}$ & $212,24 \mathrm{a}$ & $30.83 \mathrm{~b}$ \\
V13 & $14.24 \mathrm{a}$ & $3.43 \mathrm{~b}$ & $7.58 \mathrm{a}$ & $220.55 \mathrm{a}$ & $31.93 \mathrm{~b}$ \\
\hline
\end{tabular}

The means followed by the same letter are not different from each other at a $5 \%$ probability level $(\mathrm{p}<0.05)$ according to a Scott-Knott test. 
the survival of seedlings grown in full sun, this characteristic is favorable, since leaves with high leaf areas tend to experience more evapotranspiration (Damatta \& Rena, 2000).

Furthermore, the number of leaves of genotype V11 is not different from that of the other genotypes; nevertheless, V11 is among the genotypes that have relatively high leaf areas (Table 6). Consequently, this results in larger leaves and, combined with the high SPAD index value, provides a greater capacity to absorb radiation, which results in a higher photosynthetic rate. This result can be seen in Table 7; genotype V11 had the highest carbon uptake (i.e., the greatest mass of total dry matter).

Table 7 shows the values of the dry matter mass divided into the aerial parts of the plants, the roots, and the total mass. Concerning the aerial parts of the plants, smaller averages were found for genotypes V4, V7 and V9 than for the other genotypes. These genotypes also presented the lowest average values for the root systems, together with V12 and V13.

The values of the root dry mass obtained in this experiment ranged from 0.50 to $0.95 \mathrm{~g}$, accord- ing to the genotypes analyzed. Genotype V8 presented a value of $0.78 \mathrm{~g}$, close to that found by Berilli et al. (2018b), in which a mean value of $0.85 \mathrm{~g}$ was discovered for the same genotype after cultivating plants in substrate with the addition of $20 \%$ tannery sludge, $20 \%$ humus and $50 \%$ soil for 210 days.

When the total dry matter mass was evaluated (Table 7), it was observed that genotypes V4, V7 and V9 had the lowest values. Genotypes V7 and V9 presented values of 3.06 and $2.60 \mathrm{~g}$ of total dry matter mass, which were lower than that of V11 by more than $29 \%$ and $39 \%$, respectively. Hence, the smaller leaf area obtained by genotypes V7 and V9 (Table 6) interfered with the mass production of total dry matter, that is, carbon fixation. This is because the leaf area of a plant is mainly responsible for the photochemical stage of the plants, generating energy and consequently participating in the production of photoassimilates, which will be responsible for maintenance and growth (Sales et al., 2017).

The values of the total dry matter mass found in this study were higher than those obtained by

Table 7. Mean values of the dry matter mass of the aerial parts of the plants (APDMm), root dry matter mass $(\mathrm{RDM} m)$, total dry matter mass (TDMm), Dickson quality index (DQI) of the seedlings and leaf area ratio (LAR) of "Vitória Incaper 8142" conilon coffee seedlings

\begin{tabular}{lccccc}
\hline Genotypes & $\begin{array}{c}\text { APDM } m \\
(\mathrm{~g})\end{array}$ & $\begin{array}{c}\text { RDM } m \\
(\mathrm{~g})\end{array}$ & $\begin{array}{c}\text { TDM } m \\
(\mathrm{~g})\end{array}$ & $\begin{array}{c}\text { DQI } \\
\left(\mathrm{cm}^{2} \mathrm{~g}^{-1}\right)\end{array}$ \\
\hline V1 & $3.18 \mathrm{a}$ & $0.75 \mathrm{a}$ & $3.93 \mathrm{a}$ & $0.47 \mathrm{a}$ & $65.97 \mathrm{a}$ \\
V2 & $3.09 \mathrm{a}$ & $0.76 \mathrm{a}$ & $3.84 \mathrm{a}$ & $0.49 \mathrm{a}$ & $56.03 \mathrm{a}$ \\
V4 & $2.62 \mathrm{~b}$ & $0.63 \mathrm{~b}$ & $3.26 \mathrm{~b}$ & $0.41 \mathrm{~b}$ & $61.22 \mathrm{a}$ \\
V5 & $2.91 \mathrm{a}$ & $0.74 \mathrm{a}$ & $3.65 \mathrm{a}$ & $0.51 \mathrm{a}$ & $59.45 \mathrm{a}$ \\
V6 & $2.97 \mathrm{a}$ & $0.72 \mathrm{a}$ & $3.69 \mathrm{a}$ & $0.48 \mathrm{a}$ & $62.62 \mathrm{a}$ \\
V7 & $2.48 \mathrm{~b}$ & $0.58 \mathrm{~b}$ & $3.06 \mathrm{~b}$ & $0.36 \mathrm{~b}$ & $62.37 \mathrm{a}$ \\
V8 & $3.01 \mathrm{a}$ & $0.78 \mathrm{a}$ & $3.79 \mathrm{a}$ & $0.47 \mathrm{a}$ & $59.07 \mathrm{a}$ \\
V9 & $2.10 \mathrm{~b}$ & $0.50 \mathrm{~b}$ & $2.60 \mathrm{~b}$ & $0.32 \mathrm{~b}$ & $55.21 \mathrm{a}$ \\
V10 & $3.30 \mathrm{a}$ & $0.75 \mathrm{a}$ & $4.05 \mathrm{a}$ & $0.47 \mathrm{a}$ & $59.91 \mathrm{a}$ \\
V11 & $3.31 \mathrm{a}$ & $0.95 \mathrm{a}$ & $4.26 \mathrm{a}$ & $0.56 \mathrm{a}$ & $57.19 \mathrm{a}$ \\
V12 & $2.93 \mathrm{a}$ & $0.64 \mathrm{~b}$ & $3.56 \mathrm{a}$ & $0.43 \mathrm{~b}$ & $59.99 \mathrm{a}$ \\
V13 & $2.86 \mathrm{a}$ & $0.58 \mathrm{~b}$ & $3.45 \mathrm{a}$ & $0.38 \mathrm{~b}$ & $63.17 \mathrm{a}$ \\
\hline
\end{tabular}

The means followed by the same letter are not different from each other at a $5 \%$ probability level $(\mathrm{p}<0.05)$ according to a Scott-Knott test. 
Berilli et al. (2014). These authors cultivated conilon coffee seedlings in a conventional substrate (soil + cattle bovine manure + sand in 1:1:1 ratio); 120 days after planting, a total dry matter mass of $2.38 \mathrm{~g}$ was obtained. However, the experiment was kept in the field for 30 days less, which contributed to the lower results.

The best values of the Dickson quality index for the seedlings (Table 7) were obtained for genotypes V1, V2, V5, V6, V8, V10, and V11. It is worth mentioning that this index takes into account the balance in the distribution of biomass throughout the plant. In addition, the higher the index, the better the quality of the seedlings. No statistically significant differences were observed for the leaf area ratio. This shows that, in general, the genotypes used in the study presented the same increase in dry matter per unit of leaf area.

Table 8 shows that for the chlorophyll index, higher values were observed for genotypes V9 and V11. This confirms the values obtained by the SPAD (Table 3), for which the same genotypes had the highest averages. For the flavonoid index, genotypes V1, V2, V6, and V13 stand out as having higher average values than the other genotypes. The higher production of this secondary metabolite by these genotypes may indicate their sensitivity to the chromium and sodium found in the tannery sludge, which can accumulate in the different tissues of the plants and may lead to changes in the chloroplasts (Berilli et al., 2016; Berilli et al., 2018c).

According to Kandil et al. (2004), stressed plants tend to produce a greater amount of flavonoids as well as other polyphenols. Thus, the amount of chromium and sodium present in the substrate was sufficient to raise the levels of this compound in genotypes V1, V2, V6, and V13, although they did not cause toxicity since these genotypes showed proper growth and good quality. Greater results were found by Quartezani et al. (2018) for V2, with values of 0.63 for the flavonoid index, using substrates with $85 \%$ soil and $15 \%$ tannery sludge (v/v).

Hence, the use of foliar fertilization in seedlings is necessary, since it guaranteed a greater leaf area of the plants as well as a greater accumulated total dry matter, reaching increases of more than $20 \%$ compared to those in the plants without fertilization. According to the recommendations of

Table 8. Mean values of chlorophyll (SFR-R), nitrogen balance (NBI-R), and flavonoids (FLAV) obtained by using a Multiplex ${ }^{\circledR}$ device with "Vitória Incaper 8142 " conilon coffee seedlings

\begin{tabular}{llll}
\hline Genotypes & SFR-R & NBI-R & FLAV \\
\hline V1 & $2.62 \mathrm{~b}$ & $1.82 \mathrm{c}$ & $0.45 \mathrm{a}$ \\
V2 & $2.65 \mathrm{~b}$ & $2.01 \mathrm{c}$ & $0.42 \mathrm{a}$ \\
V4 & $2.54 \mathrm{~b}$ & $2.74 \mathrm{~b}$ & $0.20 \mathrm{c}$ \\
V5 & $2.80 \mathrm{~b}$ & $2.37 \mathrm{c}$ & $0.22 \mathrm{c}$ \\
V6 & $2.88 \mathrm{~b}$ & $1.40 \mathrm{c}$ & $0.46 \mathrm{a}$ \\
V7 & $2.88 \mathrm{~b}$ & $3.45 \mathrm{a}$ & $0.19 \mathrm{c}$ \\
V8 & $2.93 \mathrm{~b}$ & $2.90 \mathrm{~b}$ & $0.21 \mathrm{c}$ \\
V9 & $3.46 \mathrm{a}$ & $3.95 \mathrm{a}$ & $0.22 \mathrm{c}$ \\
V10 & $2.77 \mathrm{~b}$ & $2.15 \mathrm{c}$ & $0.30 \mathrm{~b}$ \\
V11 & $3.15 \mathrm{a}$ & $2.87 \mathrm{~b}$ & $0.26 \mathrm{~b}$ \\
V12 & $2.70 \mathrm{~b}$ & $2.25 \mathrm{c}$ & $0.31 \mathrm{~b}$ \\
V13 & $2.68 \mathrm{~b}$ & $2.51 \mathrm{c}$ & $0.39 \mathrm{a}$ \\
\hline
\end{tabular}

The means followed by the same letter are not different from each other at a $5 \%$ probability level $(\mathrm{p}<0.05)$ according to a Scott-Knott test. 
CEPLAC (2018), foliar fertilization is necessary for coffee plants soon after the emergence of the second pair of leaves. In addition, tannery sludge added to the substrate appeared to be an excellent alternative to coffee seedling producers, since no toxicity was observed in the seedlings.

Leaf fertilization provided the most significant improvements for all the evaluated growth characteristics, leading to the best qualities in the plants. Nevertheless, it did not exert a significant effect on the secondary metabolism or chlorophyll indexes. The V7 and V9 genotypes presented smaller leaf areas, which resulted in less carbon fixation and lower total dry matter masses. Despite the greater indexes of flavonoids in genotypes V1, V2, V6, and V13, no deleterious effects were found in the total dry matter mass gain.

\section{Acknowledgment}

The authors would like to thank the Espírito Santo Research and Innovation Support Foundation (FAPES) and the Federal Institute of Education, Science and Technology of Espírito Santo (IFES) for their financial and institutional support for research.

\section{Resumen}

S.S. Berilli, R.A. Sales, H.R. Ribeiro, A.A.F. Zooca, R. A. Salles, A.P.C.G. Berilli, W.R. Ribeiro, S.J. Freitas, y T.S. Costa. 2020. Fertilización foliar en la propagación de café conilon en sustrato alternativo. Int. J. Agric. Nat. Resour. El lodo de curtiembre se ha destacado para el uso de sustratos en la propagación de las plántulas, combinando la solución de un problema ambiental con su potencial para el uso agronómico. Sin embargo, cuando un nuevo componente de fertilizante entra en la composición de un sustrato, queda por ver si otros tractos culturales se ven afectados. Por lo tanto, El objetivo de este trabajo fue verificar si la fertilización foliar suplementaria es necesaria cuando se usa sustrato con lodo de curtiduría en la propagación de plántulas de café conilon de la variedad "Vitótria Incaper - 8142". Se utilizó una disposición factorial de $2 \times 13$, siendo el primer factor la presencia o ausencia de fertilización foliar convencional, y el segundo factor fue el de 13 genotipos de conilón de café Vitoria-Incaper 8142 dispuestos en un diseño de bloques completos al azar con cuatro repeticiones. Los genotipos V7 y V9 presentaron hojas de tamaño reducido que dieron un área foliar más pequeña, y eso coincidió con una menor acumulación de masa aérea y de materia seca total. Se encontraron índices de flavonoides más altos en los genotipos V1, V2, V6 y V13, lo que indica una mayor sensibilidad de estos materiales a los componentes presentes en el lodo de curtiembre. En general, la fertilización proporcionó un mejor desarrollo inicial, así como un índice de mejor calidad de las plántulas.

Palabras clave: Coffe canephora, fisiología, propagación, sostenibilidad. 


\section{References}

Araújo, F. F. de., Tiritan, C. S., Pereira, H. M. \& Caetano Júnior, O. (2008). Desenvolvimento do milho e fertilidade do solo após aplicação de lodo de curtume e fosforita. Revista Brasileira de Engenharia Agrícola e Ambiental, 12(5):507-511.

Berilli, S. da S., Quiuqui, J. P. C., Rembinski, J. P. H. H. S., Berilli, A. P. C. G. \& Louzada, J. M. (2014). Utilização de lodo de curtume como substrato alternativo para produção de mudas de café conilon. Coffee Science, 9(4):472-479.

Berilli S. S., Zooca A. A. F., Rembinski, J., Salla, P. H .H., Almeida, J. D. \& Martineli, L. (2016). Influência do acúmulo de cromo nos índices de compostos secundários em mudas de café conilon. Coffee Science, 11(4):512-520.

Berilli, S. da S., Pereira, L. C., Pinheiro, A. P. B., Cazaroti, E. P. F., Sales, R. A. de \& Lima, C. F. (2018a). Adubação foliar com lodo de curtume liquido no desenvolvimento e qualidade de mudas de maracujá-amarelo. Revista Brasileira de Agricultura Irrigada, 12(2):2477-2486. https:// doi.org/10.7127/rbai.v12n200762

Berilli, S. da S., Martineli, L., Ferraz, T. M., Figueiredo, F. A. M. M. A., Rodrigues, W. P., Berilli, A. P. C. G., Sales, R. A., \& Freitas, S. J. (2018b). Substrate stabilization using humus with tannery sludge in conilon coffee seedlings. Journal of Experimental Agriculture International, 2(1):110. https://doi.org/10.9734/JEAI/2018/39851

Berilli, S. da S., Pireda, S., Trindade, F. G., Zooca, A. A. F., Berilli, A. P. C. G., Cunha, M. da, \& Sales, R. A. de. (2018c). Effect of Substrate Treated with Tannery Sludge on Growth and Anatomy of Conilon Coffee Cuttings. Journal of Experimental Agriculture International, 22(4):1-10. https:// doi.org/10.9734/JEAI/2018/40670

CEPLAC. (2018). CAFÉ. Retrieved from http:// www.ceplac.gov.br/radar/cafe.htm

CONAB, Companhia Nacional de Abastecimento. (2018). Acompanhamento da safra brasileira: café. Monitoramento agricola-Safra 2018, 5(1).

Contarato, C. C., Sobreira, F. M., Tomaz, M. A., Jesus Junior, W. C. de, Fonseca, A. F. A. da, Ferrão, M.
A. G., \& Ferrão R. G. (2010). Evaluation of the initial development of conilon coffee clones (Coffea canephora). Scientia Agraria, 11(1):65-71.

Covre, A. M., Partelli, F. L., Mauri, A. L., \& Dias M. A. (2013). Crescimento e desenvolvimento inicial de genótipos de café Conilon. Revista Agro@mbiente, 7(2):193-203. http://dx.doi. org/10.18227/1982-8470ragro.v7i2.944

Damatta, F. M., \& Rena, A. B. (2000). Relações hídricas no cafeeiro. In Simpósio De Pesquisa Dos Cafés Do Brasil, 1:1490.

Dardengo, M. C. J. D., Azevedo, J. M. G., Nery, D. D., Monteiro, V. M., \& Barbosa, R. B. (2010). Índices de qualidade e crescimento de mudas do clonilon vitória formadas em sacolas e agropote com diferentes substratos. In Congresso Brasileiro De Pesquisas Cafeeiras, 36:314.

Ferrão, R. G., Fornazier, M. J., Ferrão, M. A. G., Prezotti, L. C., Fonseca, A. D., Alixandre, F. T., \& Ferrão, L. F. V. (2008). Estado da arte da cafeicultura no Espírito Santo. In Seminário para a sustentabilidade da cafeicultura, 1:29-47.

Kandil, F. E., Grace, M. H., Seigler, D. S., \& Cheeseman, J. M. (2004). Polyphenolics in Rhizophora mangle L. leaves and their changes during leaf development and senescence. Trees, 18(5):518-528. https://doi.org/10.1007/ s00468-004-0337-8

Oberpaur, C., Fernández, C., Délano, G., \& Arévalo, M. E. (2012). Inclusion of various controlled release fertilizers in moss substrates (Sphagnum magellanicum). Ciencia e Investigación Agraria, 39(3):435-443. http://dx.doi.org/10.4067/ S0718-16202012000300004

Quartezani, W. Z., Sales, R. A de., Berilli S. da S., Aparecida, T., Pletsch, W. P. R., Campostrini, E., \& Mantoanelli, E. (2018). Effect of different sources of organic matter added to the substrate on physiological parameters of clonal plants of conilon coffee. Australian Journal of Crop Science, 12(8):1328-1334.

Restrepo, A. P., García, J. G., Moral, R., Vidal, F., Pérez-Murcia, M. D., Bustamante, M. A., \& Paredes, C. (2013). A comparative cost analysis for using compost derived from anaerobic. Ciencia 
e investigación Agraria, 40(2):253-264. http:// dx.doi.org/10.4067/S0718-16202013000200002

Sales, R. A. de, Sales, R. A. de, Nascimento, T. A. do, Silva, T. A. da, Berilli, S. da S., \& Santos, R. A. dos. (2017). Influência De Diferentes Fontes De Matéria Orgânica Na Propagação Da Schinus Terebinthifoliusradd. Scientia Agraria, 18(4):99-106. http://dx.doi.org/10.5380/rsa. v18i4.54203

Sales, R. A. de, Sales, R. A. de, Santos, R. A. dos, Quartezani, W. Z., Berilli, S. da S., \& Oliveira, E. $\mathrm{C}$ de. (2018a). Influência de diferentes fontes de matéria orgânica em componentes fisiológicos de folhas da espécie Schinus terebinthifolius Raddi. (Anacardiaceae). Scientia Agraria, 19(1):132141. http://dx.doi.org/10.5380/rsa.v19i1.51511

Sales, R. A.de, Rossini, F. P., Berilli, S. da S., Galvão, E. R., Mendes, T. P., Berilli A. P. C. G., Salles, R. A de, Sales, R. A. de, Quartezani, W. Z., \& Freitas, S. de J. (2018b). Foliar Fertilization Using Liquid Tannery Sludge in Conilon Coffee Seedlings Production. Journal Of Experimental Agriculture International, 22(2):01-08. https:// doi.org/10.9734/JEAI/2018/40201
Sales, R. A., Oliveira, E. C., Delgado, R. C., Leite, M. C. T., Ribeiro, W. R., \& Berilli, S da S. (2018c). Sazonal and interanual rainfall variability for Colatina, Espirito Santo, Brazil. Scientia Agraria, 19(2):186-196.

Silva, L. G. F., Sales, R. A., Rossini, F. P., Vitória, Y. T., \& Berilli, S. S. (2019). Emergência e desenvolvimento de plântulas de maracujá-amarelo em diferentes substratos. Energia na agricultura, 34(1):18-27. https://doi.org/10.17224/ EnergAgric.2019v34n01p18-27

Streit, N. M., Canterle, L. P., Canto, M. W. do, Hecktheuer, L. H., \& Hychecki. (2005). As Clorofilas. Ciência Rural, 35(3):748-755. http://dx.doi. org/10.1590/S0103-84782005000300043

Tavares, L. S., Scaramuzza, W. L. M. P., Weber, O. L. S., Valadão, F. C. A., \& Maas, K. D. B. (2013). Lodo do curtimento e sua influência na produção de mudas de paricá (Schizolobium amazonicum) e nas propriedades químicas do solo. Ciência Florestal, 23(3):357-368. http://dx.doi. org/10.5902/1980509810547 